\title{
EPICAUTA DIVERSICORNIS AND ITS ALLIES IN THE NEOTROPICAL REGION (COLEOP., MELOID $\nexists)^{1}$
}

\author{
By F. G. Werner
}

Biological Laboratories, Harvard University

Epicauta diversicornis and related species form a closely-knit group which can be defined as possessing the following characters in the male. Posterior tibiæ with a row of short teeth internally at the apex. First two antennal segments enlarged, denuded except for scattered erect setæ, and shiny, the first not excavated externally at the tip. Anterior tibiæ with a single spur and anterior tarsi with the first segment flattened, usually shiny and expanded.

All of the known species in the group are moderately slender and almost uniform in width (see figure in Champion, 1892). Except for size and color there is great similarity in all the species. None has been seen less than ten millimeters long or more than twenty. Females can be known by the distinctive shape and usually can be placed by color and locality. All the species have a small scutellar and humeral spot on the elytra when fully marked. There are several species outside the group which have females similar to those in the group so that caution should be observed when making determinations.

Attention should be called to the variation that occurs in the width of the first two antennal segments of the male. An example is shown in figures 4 and 5, both of diversicornis. This much variation occurs also in isthmica and probably in the other species with these segments flattened.

All the known species of Epicauta with the posterior tibial comb are restricted to the region from Southwestern

1 Published with a grant from the Museum of Comparative Zoology at Harvard College. 
United States to Guiana and Colombia. The diversicornis group is interesting in that it contains the only species known to occur in South America.

A key to the males of the known species follows. Except where noted, all specimens on which ranges are based have been examined by the author.

1. First antennal segment triangular in cross-section, with three almost flat surfaces

First antennal segment flattened or oval in crosssection, with at most two flat surfaces ........................... 4

2. First tarsal segment slightly longer than second, with uniform sparse pubescence. Antennæ as in figure 2. Brown, clothed with cinereous pubescence, which is denser in a line down each elytron. Mexico: Nayarit (Tepic), Morelos (Cuernavaca), Yucatan (Chichen Itza) ................... E. forticornis (Haag), 1880 First tarsal segment shorter than second, denuded, shiny

3. First two antennal segments equal to rest in length. Black, the elytra luteous, uniformly clothed with cinereous to luteous pubescence. U.S.: Texas (Val Verde Co. to El Paso Co.), New Mexico (southern), Arizona (Douglas, Sta. Catalina Mts.). Mexico: Nuevo Leon (Monterrey) ........E. polingi Werner, 1943 First two antennal segments longer than the rest. Brown, with the margins of the elytra paler and with paler pubescence. U.S.: Arizona (Maricopa Co. to Gila Co.). Mexico: Sonora (Imuris).

E. liebecki Werner, 1943

First two antennal segments shorter than the rest. Brown to luteous, with uniform cinereous pubescence. U.S.: Arizona (Maricopa Co. to Cochise Co.). Mexico: Sonora (Arizpe)

E. arizonica Werner, 1943

4. Second antennal segment distinctly more than half as long as first. Fig. 1 and fig. 3 5 Second antennal segment half as long as first or shorter. Fig. 4 to fig. 8.

5. First segment of anterior tarsi longer than second, not expanded and with at least scattered pubescence. 
Antennæ as in fig. 1. Body brown, elytra luteous, with uniform pale pubescence. Mexico: Jalisco (Guadalajara), Nayarit (Tepic, fide Dugès), Morelos (Cuernavaca) $E$. humeralis (Dugès), 1889 First segment of anterior tarsi shorter and broader than second, partly denuded and shiny. Brown, with the margins of the elytra paler and with a fringe of denser pubescence. Antennæ as in fig. 3. Guiana fide Erichson, Venezuela (Las Trincheras), Colombia (Amaya-Cispata Bay), Panama (Ft. Clayton, C.Z.) [= Lytta intermedia Haag, 1880]

E. flagellaria (Erichson), 1848

6. Second antennal segment distinctly longer than the following three. Fig. 4 and fig. 5. Black or dark brown, the elytra luteous. First segment of the anterior tarsi subequal to second, slightly expanded, shiny. Mexico: Sinaloa (Mazatlan, Venodio), Nayarit (Tepic), Jalisco (Guadalajara), Michoacan (Apatzingan), Hidalgo (Pachuca), D.F. (Mexico City), Morelos (Cuernavaca), Guerrero (Acapulco), Vera Cruz (Cordoba). [= Macrobasis flavens Dugès, = Macrobasis diversicornis, Champion, in part.]

E. diversicornis (Haag), 1880

Second antennal segment at most slightly more than equal to the following two. Fig. 6 to fig. 8 .

7. Second antennal segment slightly longer than the following two. First segment thickened, oval in crosssection. See fig. 6. Dark brown to black, with the margins of the elytra fringed with pale pubescence. Averaging smaller than diversicornis and the other species in the group in its region. Mexico: Durango (Canelas, fide Dugès), Jalisco (Colima Vulcano), Nayarit (Tepic). E. beckeri (Dugès), 1889 Second segment of antennæ slightly longer than the following two. First segment flattened. See fig. 7. Dark brown, with uniform pale to dark pubescence. As small as beckeri, usually less than $12 \mathrm{~mm}$. Guatemala (Guatemala City), Mexico (Chiapas), Salvador (Sta. Ana). E. candèzi (Haag), 1880 Second segment of antennæ only slightly longer 
than the third. See fig. 8. Middle tarsi with a fringe of long hairs along the inside. Panama to Vera Cruz. E. isthmica $\mathrm{sp} n$.

Epicauta isthmica sp. $n$.

Length: 10 to $20 \mathrm{~mm}$. Body black, elytra brown to luteous; legs except for tarsi, palpi, labrum, labium and clypeus luteous. Pubescence uniform, moderately dense, decumbent, cinereous to pale luteous. There is a dark scutellar and humeral spot, dark pubescence on the tarsi (some pale pubescence at the base of the first segments) and on the tips of the femora and outer edge of the tibiæ. No dark pubescence on the abdominal sternites except on the apex of the fifth. Any of this dark pubescence may be greatly reduced or even absent.

Head subquadrate; eyes prominent, transverse, excavated but moderately broad, four-sevenths as long as broad at the broadest place when seen from the side, separated dorsally by an area slightly narrower than their greatest width. Surface of head densely but finely punctured, uniformly, densely microreticulate. Antennal calluses narrow, denuded, without punctures. Median impressed line distinct down to the level of the eyes, not augmented by a denuded border. Mouth parts except for mandibles luteous. Last segment of maxillary palpi quite narrow, half as long as wide at the widest place, two-thirds from the base. Male antennæ as in figure 8 or with the first two segments broader or slightly narrower, the first two segments black to luteous. Female antennæ as in diversicornis but with the second segment slightly shorter than the third.

Pronotum narrower than head, one-third longer than broad. Sides roughly parallel for the basal three-fourths, then converging at a sixty degree angle, the side slightly arcuate and the change in angle not abrupt. Basal impressed line distinct. Median impressed line fine but distinct. Surface more densely punctured than on head. Scutellum black. Elytra brown to luteous, with the luteous form more prevalent in the northern part of the range. 
Underside uniformly pale pubescent, except for the apical half of the fifth abdominal sternite. The apices of the abdominal sternites have a fringe of slightly denser pubescence so that they appear indistinctly margined.

Anterior tibiæ of male denuded externally, with one straight, spiniform apical spur. First segment of male anterior tarsi denuded except for a few hairs along the outer margin and apex, shiny, expanded on the inner margin, concave behind. Middle tarsi of male with a fringe of long erect black hairs along the inside. Each hair of this fringe is as long as the fourth segment. Posterior tibial spurs expanded spiniform, the outer shorter than the inner.

Holotype : $0^{\lambda}$, Cabima, Panama May 28, 1911 A. Busck (USNM)

Allotype: $q$, eutopotypical (USNM)

Paratypes: Panama: $70^{\star}, 6 \circ 9$, topotypical (USNM); $20^{\lambda}$, Bocas del Toro (USNM) ; $20^{\lambda} 0^{\lambda}, 1$, , Taboga I. (USNM) ; 2q9, La Chorrera (USNM) ; 40ㅊ, 4우, La Chorrera (Cal. Ac.) ; 10, 3우, St. Maria, El Real (MCZ) ;

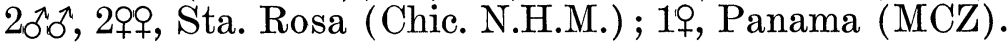

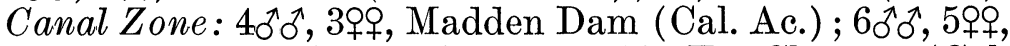

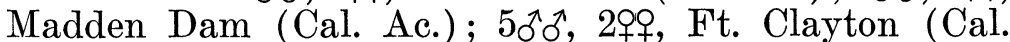
Ac.) ; 19 , Gamboa (Cal. Ac.) ; $2{ }^{\lambda} \sigma^{\lambda}$, Ancon (Chic. N.H.M.) 10, 1ㅇ, Ancon (Ohio) ; 19, Ancon (USNM) ; 19, Culebra

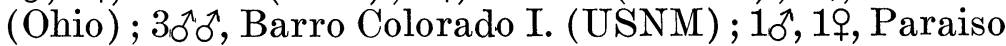
(USNM); 10 $0^{\lambda}$, Tabernilla (USNM); 19, Alhajuelo

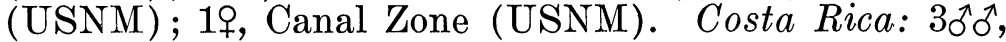

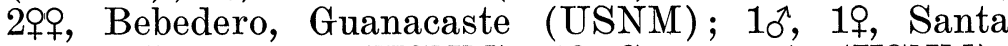
Elena, Guanacaste (USNM) ; 19, Guanacaste (USNM) ;

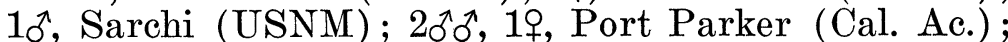
2o+o, Costa Rica (Chic. N.H.M.). Nicaragua: 19, Managua (USNM). Honduras: 10, 19, La Libertad, Comay (MCZ) ; 10 ${ }^{\lambda}$, San Pedro S. (Chic. N.H.M.). Salvador: $1{ }^{\lambda}$, Santa Ana (USNM). British Honduras: 19, Punta

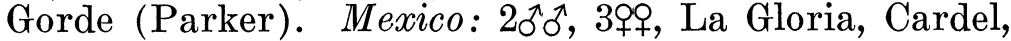

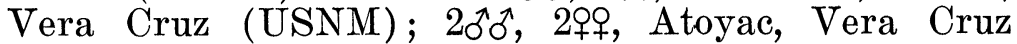
(USNM). 
Explanation of Plate 5

Male antennæ. Cross-section of first segment on left. Fig. 1. Epicauta forticornis (Haag)

Fig. 2. Epicauta humeralis (Dugès)

Fig. 3. Epicauta flagellaria (Erichson)

Fig. 4. Epicauta diversicornis (Haag)

Fig. 5. Epicauta diversicornis (Haag)

Fig. 6. Epicauta beckeri (Dugès)

Fig. 7. Epicauta candèzi (Haag)

Fig. 8. Epicauta isthmica sp. n. 


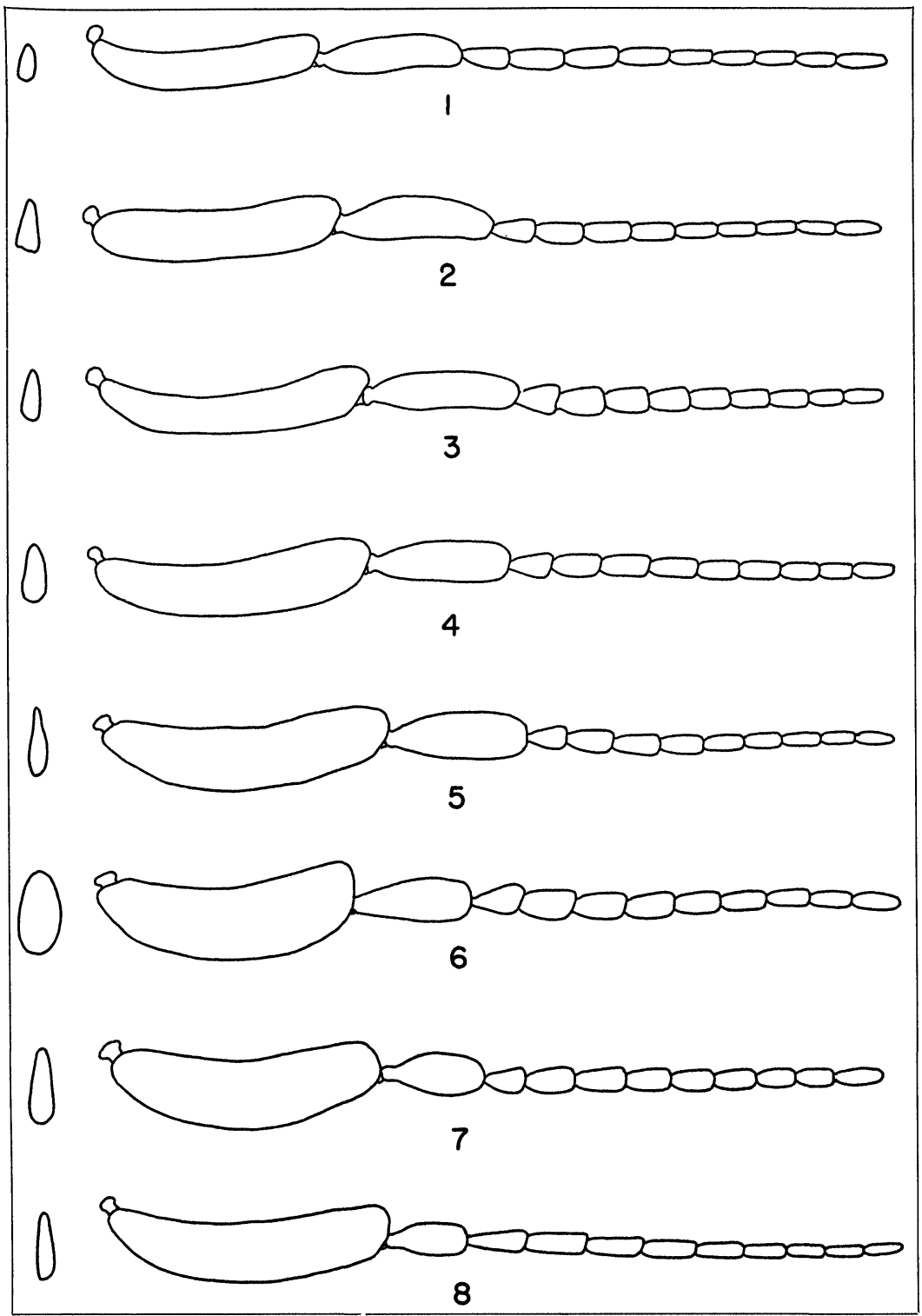

WERNER-EPICAUTA DIVERSICORNIS 

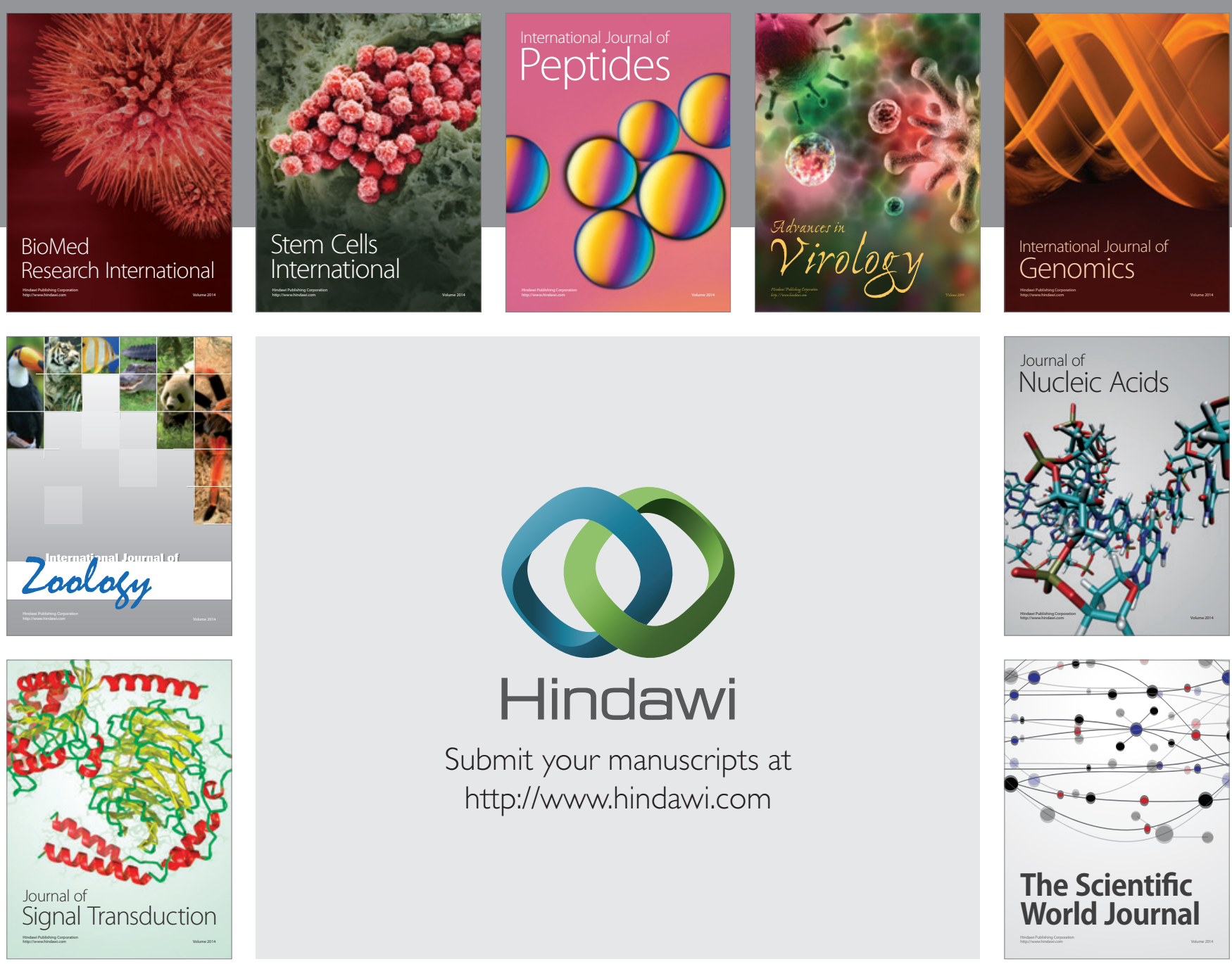

Submit your manuscripts at

http://www.hindawi.com
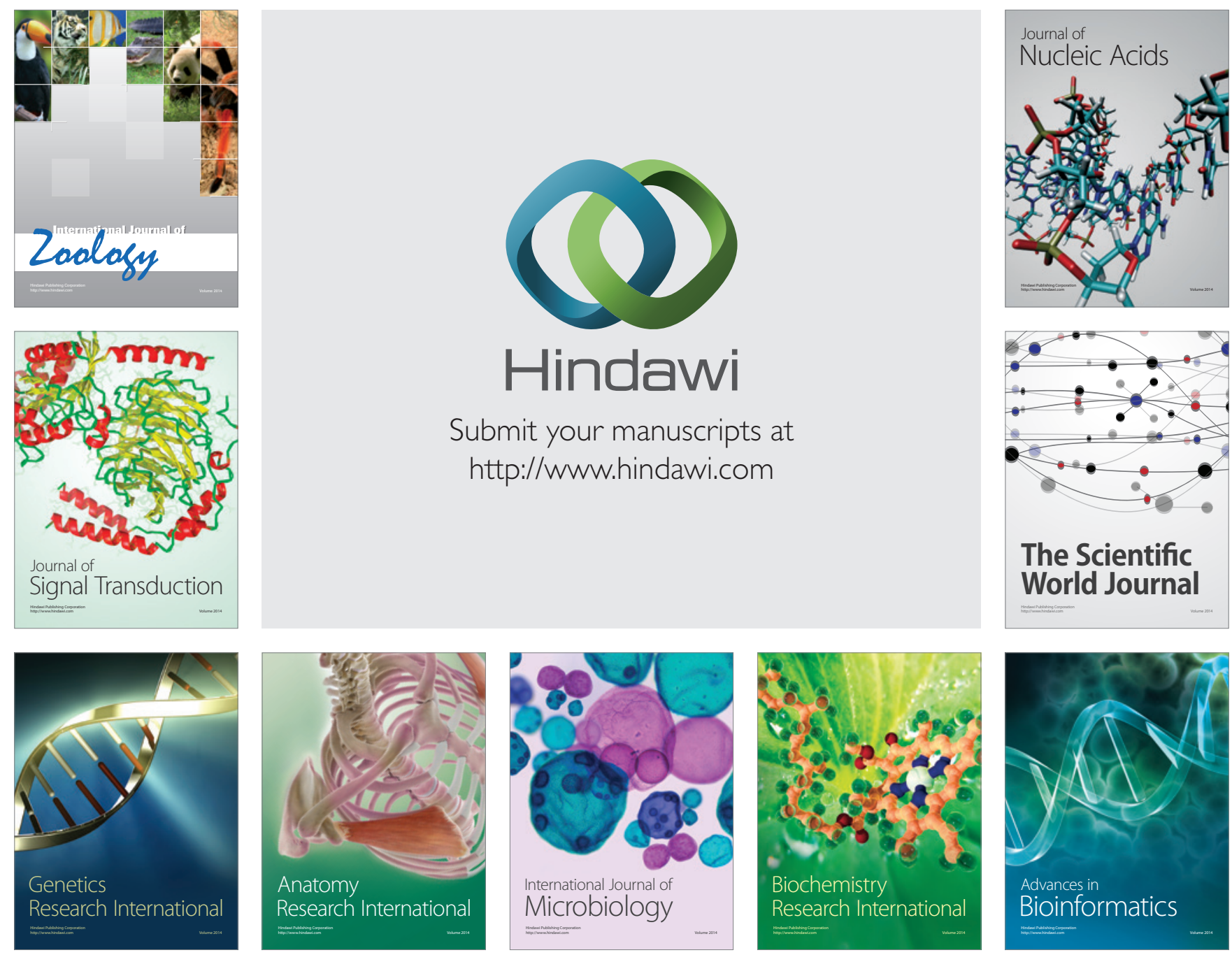

The Scientific World Journal
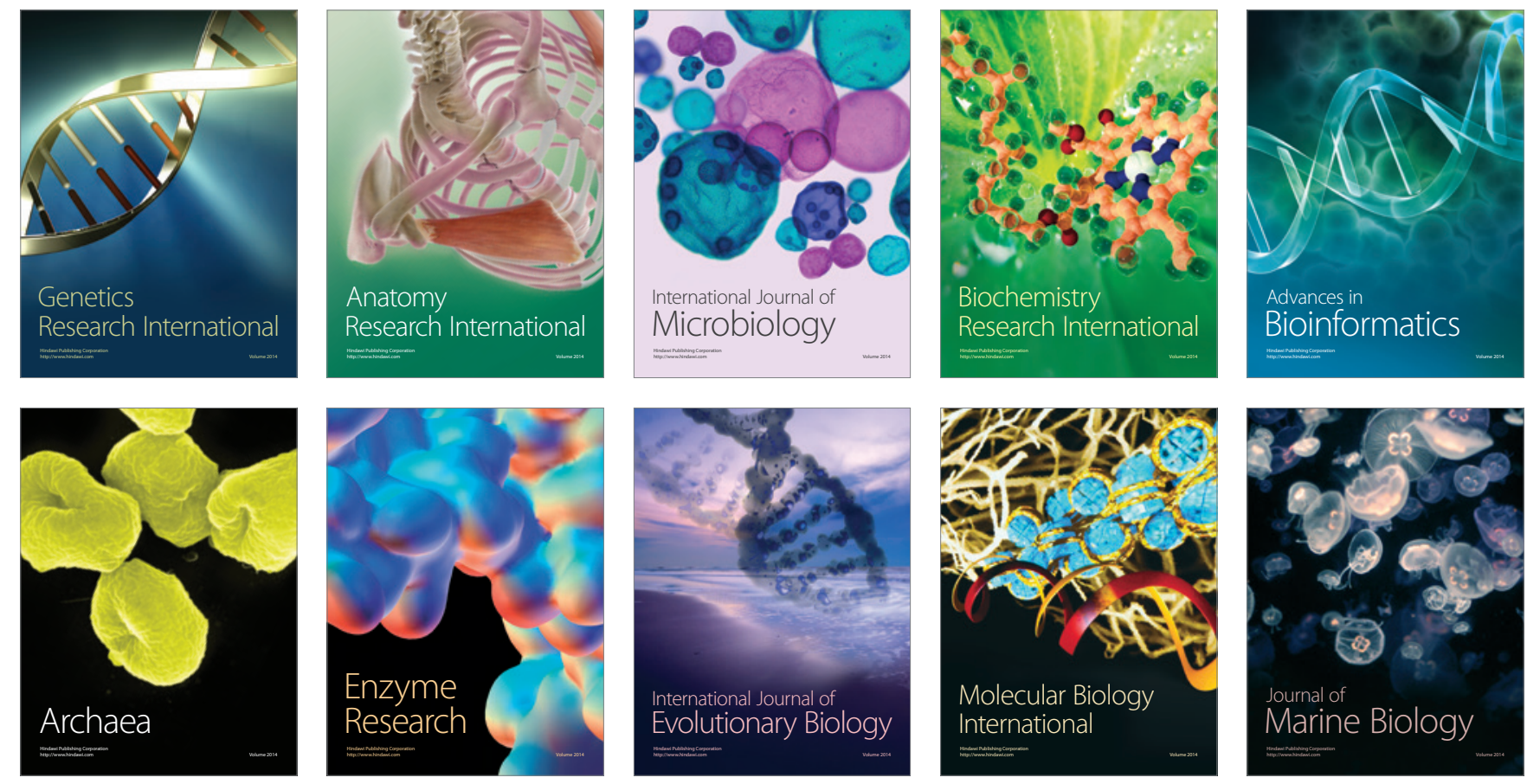